\title{
Test Maddelerinin Bilim Felsefesi Bağlamında Değerlendirilmesi
}

\section{Evaluation of Test Items in the Context of Science Philosophy}

\author{
Dr. Öğr. Üyesi Duygu KOÇAK ${ }^{(D)} 1$
}

$\ddot{\mathbf{O z}}$

Ölçme ve değerlendirme, dolayısıyla testler eğitim sisteminin önemli bir bileşenidir. Eğitim programları, öğretim yöntem ve teknikleri ve öğrenme alanları genellikle eğitim felsefesi çerçevesinde değerlendirilirken, ölçme ve değerlendirme kavramı felsefi açıdan değerlendirilmemiştir. Bu çalışmada, bilimin tarihsel gelişimi ve bilim felsefesi ışığında eğitimde kullanılan ölçme araçlarının değerlendirilmesi yapılmıştır. Buna göre, çoktan seçmeli, doğru-yanlış, boşluk doldurmalı, kısa cevaplı, eşleştirme, açık uçlu madde yapıları ve sözlü sınavlar ile performansa dayalı durum belirleme teknikleri pozitivist ve postpozitivist yaklaşımlar çerçevesinde değerlendirilmiştir. Performansa dayalı durum belirleme, açık uçlu sınavlar ve sözlü sınavların bireye yanıtlamada özgürlük tanıması, tek bir mutlak doğru içermemesi ve sürecin ön plana çıkması bakımından post-pozitivist paradigma ile etkileşimli olduğu değerlendirmesi yapılmıştır. Bu değerlendirmelerin ardından pozitivist paradigmayı ve post-pozitivist paradigmayı temel alan madde yapılarının eğitim hedeflerine ve bireye olan katkıları tartışılmışır. Post-pozitivist paradigmayı temel alan madde yapılarının ve değerlendirme yaklaşımının eğitim hedeflerine ulaşmada ve bireye özgür düşünme imkânı tanıması bakımından önemli olduğu yargısına varılmıştır.

Anahtar Kelimeler: Bilim felsefesi, test, madde türleri, pozitivizm, post-pozitivizm

Makale Türü: Derleme

\begin{abstract}
Measurement and evaluation, therefore, tests are an important part of the education system. While education programs, teaching methods and techniques and learning curriculums are generally evaluated within the framework of educational philosophy, the concept of measurement and evaluation has not been evaluated philosophically. In this study, based on the historical development of science and philosophy of science, the evaluation of the scale tools used in education was made. Accordingly, multiple-choice, true-false, gapfilled, short-answer, matching, essay item types and oral examinations and performance-based assessment techniques were evaluated within the framework of positivist and post-positivist approaches. Performancebased assessment techniques, open-ended exams and oral examinations were considered to be free to respond to the individual and to interact with the post-positivist paradigm in order for the process to come to the fore. Following these evaluations, the contribution of the item structures based on the positivist paradigm and post-positivist paradigm to the educational objectives and the individual were discussed. It is concluded that item structures and evaluation approach based on post-positivist paradigm are important in achieving educational goals and in providing free thinking to the individual.
\end{abstract}

Keywords: Science philosophy, test, item types, positivism, post-positivism

Paper Type: Review

\footnotetext{
${ }^{1}$ Alanya Alaaddin Keykubat Üniversitesi, Eğitim Fakültesi, duygu.kocak@alanya.edu.tr.

Atıf için (to cite): Koçak, D. (2019). Test Maddelerinin Bilim Felsefesi Bağlamında Değerlendirilmesi. Afyon Kocatepe Üniversitesi Sosyal Bilimler Dergisi, 21(Prof. Dr. Fuat Sezgin Özel Sayısı), 1-15.
} 


\section{Giriș}

Bilim felsefesinin odağında bilimin felsefi olarak incelenmesi yatmaktadır. Buna göre bilim felsefesi bilimin yapısını, işleyişini ve bilimsel metodu ele almaktadır. Bilim nasıl ilerlemektedir, bilimsel bilgi nedir, bilimsel bilgiyi diğer bilgilerden ayıran özellikler nelerdir, bilimsel bilgiye ulaşmanın yolu ya da yolları nelerdir sorularına bilim felsefesi yanıt aramaktadır. Örneğin bilimsel bilgi nedir sorusuna verilecek yanıtlar sosyal bilimler alanında ve fen bilimleri alanında inceledikleri özellikler ve bilgiye ulaşma yolları farklı olduğu için farklı olacaktır. Bunun araştırılması da yine bilim felsefesinin konusudur (Ural, Kaya, Duralı, Sözer ve Erdemli, 1994: 3). Bilim felsefesi alanında bu sorulara verilen yanıtlar bilime bakış açısını yansıtmaktadır. Bir diğer ifadeyle bilimin, bilimsel bilginin, bilimsel yöntemin ne olduğu sorularına bir yaklaşımla yanıt aranmaktadır. Bu yaklaşımlar paradigma olarak ifade edilmektedir ve bilim felsefesi alanında pozitivist ve post-pozitivist paradigmalar temel olmak üzere farklı yaklaşımlar bulunmaktadır. Bilim felsefesinin gelişimini, ayrı bir alan olarak ilerlemesini ve farklı bilimsel yaklaşımların ortaya çıkış nedenlerini anlamak için bilimin tarihsel gelişimini de göz önünde bulundurmak önemlidir.

Bilimin tarihsel gelişimi, bilimin ortaya çıkışından günümüze gelene kadar hangi aşamalardan geçtiğini ifade etmektedir. Bilim tarihi ise bilimin bilim olarak tanımlanmasını, ortaya çıkışını, ortaya çıkış nedenlerini ve geçtiği süreçleri inceler. Bilim tarihinde yer alan gelişmelerin tümünde toplumun ihtiyaçlarının belirleyici olduğu söylenebilir. Örneğin suya olan ihtiyaç nedeniyle nehir kıyılarına yerleşilmiştir, bu nehirlerden biri de Nil nehridir ve Nil nehri etrafına yerleşen Mısırlılar, çeşitli dönemlerde nehrin taşması sonucu su baskınları yaşamaktadır. Elbette ki bu yaşam ve tarım alanları açısından büyük sorun teşkil etmektedir, buna çözüm arayışları sonucu nehrin taşma dönemlerine dair bir tahmin yürütmüşlerdir. Her ne kadar güneş ve ay tutulmalarını önceden kestiremeseler de sabit yıldızları ve gezegenleri birbirinden ayırabiliyorlardı. $\mathrm{Bu}$ gözlemler beraberinde takvimi getirmiştir. Nehrin taşmasına engel olunamasa da, yaşamlarını ve özellikle tarım işlerini buna göre düzenlemişlerdir. Buna göre, sene dörder aylık üç mevsimden oluşmaktadır, bunlar: Nil nehrinin taşması, tohum atma ve ekin biçme mevsimleridir. Gök yüzüne ilişkin gözlemlerin, sabit yıldızların ve takım yıldızlarının gözlenmesi bilime bir katkı sağlamak için yapılmamıștır, bu takvim tasarımında Mısırlıların ihtiyaçlarının belirleyici olduğu aşikardır. Bilim alanındaki gelişmeler İlk Çă̆' da, Orta Çağ'da, Rönesans'ta ve Rönesans'tan sonra olacak şekilde farklı dönemlerde değerlendirilebilir.

\subsection{Bilimin Tarihsel Gelişimi}

Sümer, Mısır ve Babil uyarlıklarının bilim tarihinin başlangıcı sayılan gelişmeleri yapmış olmaları nedeniyle bilim tarihine katkıları büyüktür. Sümerlerde yazının kullanılması, bilimin başlangıcına denk gelmektedir, Babiller günümüzde hala geçerliğini koruyan, bir günü 24 saat, saati 60 dakika, dakikayı ise 60 saniye olarak hesaplamışlardır. Mısırlıların sabit yıldızlara ilişkin gözleminin dışında, tarım arazilerini korumak amacıyla konum belirlemeye yönelik alan ve hacim hesaplamaları yaparak geometriye önemli katkılar sunduğu bilinmektedir. Sümerlerin ise geometriye en önemli katkılarından biri Pi sayısını 3 olarak almalarıdır. Sümer, Mısır ve Babil uygarlıklarının gözleme ve ölçüme dayalı katkılar sunduğu görülmektedir (Yıldırım, 1997: 218 ). Bu yönüyle Orta çağ öncesinde pozitivist paradigmanın temellerinin atıldığı söylenebilir. Ortaçağ öncesi dönemde Antik Yunan düşünürlerinin de bilime düşünsel katkıları yadsınamaz. Özellikle evrenin temel niteliğini anlamaya odaklanarak felsefe alanında önemli gelişmeler sağlamışlardır (Gökberk, 1999: 147). Felsefe alanına olan bu katılarıyla bilimin akıl ve düşünme yönüne yön vermişlerdir. Antik Yunan düşünürlerinin ise evrenin niteliği ve nesnelerin ortak tözünü bilme uğraşları düşünme yoluna dayanmaktadır. Bu yönüyle bilgiye ulaşmada gözlem ve ölçme dışında bir yolun varlığını ortaya koydukları dolayısıyla post-pozitivist paradigmaya zemin oluşturdukları söylenebilir. Ortaçağ öncesinde bilimsel ilerlemenin gözlem ve ölçme yönünü Babil, Mısır ve Sümer uygarlıkları; akıl ve düşünme yönünü ise Antik Yunan düşünürleri doldurmuşlardır (Yildırım, 1997: 33). 
Roma imparatorluğunun M.S. 5. yüzyılda yıkılmasından, 15. yüzyılda Rönesans'ın doğuşuna kadar geçen süre Orta Çağ olarak anılmaktadır. Bu süreçte Batı Avrupa'da Hristiyanlığın egemen olduğu bir düşünce sistemi hakimdir ve buna göre bir fikrin kabul görmesinin tek yolu Hristiyanlıkla bağdaşması ve kilisenin onayından geçmesidir (Koçak, 2019: 29). Bu yönüyle bilimin kilise ve din adamlarının tekelinde olduğu söylenebilir, üstelik aksi görüşün kabul görmemesinin yanında bu görüşü savunanları da ağır cezalar beklemektedir. Gözleme dayalı güneşin merkezde olduğu evren tasarımı kesinlikle kabul görmemektedir. Antik Yunan düşünürlerinden Aristotales'in evren yaklaşımı ve tanrı kavramı Orta Çağ'da Hristiyanlığın evren anlayışıyla paralellik göstermektedir. Bu dönemde Orta Çağ Avrupa'sında bilimsel ilerlemelerin kaydedilemediği dönemdir.

Rönesans yeniden doğuş anlamına gelmektedir. Orta Çağ'ın etkisinden kurtulan Avrupa 15. ve 16. yüzyılda Rönesans adı verilen ve İtalya'da başlayarak diğer ülkelere yayılan hareketlenme ile Orta Çağ'ın etkisinden kurtulmuştur. Orta Çağ'da matematik, fizik, kimya gibi doğa bilimlerinde duraksama yaşanırken Rönesans dönemi bilim insanları bu konularda çalışmalara ağırlık vermişlerdir. Bir önceki dönemde kilisenin baskısı ve engelleri ile yayılamayan fikirler, bu dönemde kilisenin etkisini yitirmesi ve matbaanın icadıyla yayılmaya başlamıştır. Çünkü hem fikirlerini paylaşmada kullanabilecekleri bir materyal oluşturabilir hale gelinmiştir hem de fikirlerini ifade etmeleri önünde herhangi bir engel kalmamıştır. Doğa bilimlerine yönelme sonucu özel alanlar oluşturulmuştur. Bu gelişme bilim ve bilim felsefesi açısından önemlidir çünkü bilim ve felsefenin sınırları çizilmiştir. Ayrıca bilim ve felsefe birbirinden ayrı düşünülmezken bu dönemde ele aldıkları konuların neler olduğu belirlenmiş ve sınırlar çizilmiştir. Bu dönemin en önemli gelişmelerinden biri güneş merkezli evren tasarımının kabul görmüş olmasıdır. Kopernik yer merkezli evren tasarımını bu dönemde çürütmüştür, bu durum ilerleyen dönemlerde Kepler ve Galileo tarafından da doğrulanmıştır. Yine bu dönemde Bacon'un bilim felsefesi, Descartes'in yöntem çalışmaları bilimsel araştırmaların önemini artırmıştır. Böylece süreç içinde doğa bilimlerine ağırlık verildiği ve bilimsel yöntem olarak deneysel yöntemin temel alındığı söylenebilir (Koçak, 2019: 30). Rönesans döneminde özellikle doğa bilimlerine ağırlık verilmiştir ve bu dönemde Descartes'in ele aldığı yöntem bilimi ve tartışması bilim ve felsefenin ayrılmasına yol açmıştır. Bilim insanları sosyoloji, psikoloji, biyoloji, kimya, modern fizik gibi özel alanlara yönelerek çalışmalarını sürdürmüşlerdir (Y1ldirım, 1997: 21).

\subsection{Bilim ve Felsefenin Birbirinden Ayrılması}

Rönesans döneminde hem bilim kendi içinde dallara ayrılmıştır hem de bilim ve felsefe birbirinden ayrılmıştır. Bu gelişmenin ardından 19. yüzyıl itibariyle psikoloji, sosyoloji gibi alanlar da felsefeden ayrılmışlardır. Felsefeden bu ayrılmaların olması, felsefenin konusu nedir ve neyi inceleyecektir sorularını beraberinde getirmiştir. Bu soruya bazı felsefeciler ve bilim insanları, felsefenin bilimi incelemesi ve bilimin mantığını oluşturması gerektiği yanıtını vermişlerdir (Ergün, t.y.: 5). Bilim Felsefesi'nin doğuşu bu sorulara aranan yanıtlara dayanmaktadır. $\mathrm{Bu}$ soruya yanıt ararken ilk çıkış noktası bilim ve felsefe hangi noktalarda ayrılıyor, ortak noktaları nelerdir sorularını yanıtlamak olmuştur.

Tablo 1. Bilim ve felsefenin benzer ve farklı yönleri

Faklılıkları

Benzerlikleri

Bilimin yöntemi öğretilebilirdir ancak Her ikisi de kesin, güvenilir bilgiyi elde felsefe özneldir, standart bir düşünme etmeye çalışır. biçiminden söz edilemez.

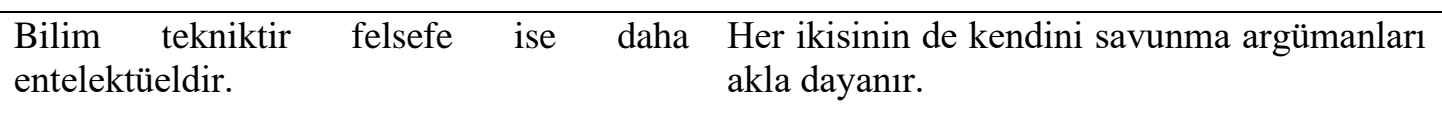




\begin{abstract}
Her bilimin konusu ve sinırları bellidir. Her ikisi de kavram ve soyutlamaları
Felsefenin konusu ise evrenseldir, her şey kullanarak ilke ve yasalara ulaşmaya çalışır felsefeye konu olabilir.
\end{abstract}

Bilim olgularla hareket eder ve ulaştığ sonucu olgularda birleştirir. Felsefe ise mantıksal çözümlemeye dayanır. Felsefenin özünü mantıksal çözümleme oluşturur.

Bilimler bilgi üretir, felsefenin böyle bir amacı ve çıktısı yoktur.

\begin{tabular}{l}
\hline $\begin{array}{l}\text { Bilimin kavram ve soyutlamaları } \\
\text { felsefeninkine göre daha az geneldir. }\end{array}$ \\
\hline $\begin{array}{l}\text { Bilimsel çalışmalar doğrulanabilir ve } \\
\text { tekrarlanabilir ancak felsefede tutarlılık } \\
\text { dışında bir denetleme yoktur. }\end{array}$ \\
\hline
\end{tabular}

Bilimlerin sunduğu bilgiler nedeniyle insanlara pratikte faydaları vardır ancak felsefenin pratikte bir faydası yoktur, insanların anlama ve bilme merakı onları felsefeye yöneltir.

Kaynak: (Ergün, t.y.:4-6; Arslan, 2007: 59; Çilingir, 2016: 2-4)

Bilim ve felsefe ayrıldıktan sonra her ikisi de kendi içinde özel çalışma alanları arayışına girmiştir ve özel alanlar tanımlanmıştır. Bu süreç bilimi anlamayı konu alan bilim felsefesinin doğuşunu beraberinde getirmiştir. Çilingir (2016)'e göre, bilim felsefesinin amacı bilim veya bilimsel bilgiyi anlamak ve açıklamaktır. Bilim felsefesi, tarihsel süreç içerisinde bilimin nasıl geliştiğini izlemek yoluyla bilimi ve bilimsel bilginin temel niteliklerini kavramayı hedefleyen bilim tarihinin yaklaşımından farklı olarak, bilimi kavram, yöntem ve ürettiği bilginin niteliği açısından ele alarak da incelemeyi hedefleyen bir uğraştır (Topdemir, 2002: 57). Peki bilim felsefesi hangi sorulara yanıt aramaktadır? Yanıt aranan sorular ve bu sürecin getirileri Tablo 2' de özetlenmiştir:

Tablo 2. Bilim felsefesinin yanıt aradı $\breve{g} 1$ sorular nelerdir?

\begin{tabular}{ll}
\hline \multicolumn{1}{c}{ Sorular } & \multicolumn{1}{c}{ Verilen yanıtlar } \\
\hline Bilimin sınırları nelerdir? & Bilimin özel alt alanlara ayrılması \\
\hline Bilimsel yöntemler nelerdir? & Nitel ve nicel araştırma ayrımının yapılması \\
\hline Bilimsel bilgi nedir? & Bilgi türlerinin ayrımının yapılması \\
\hline Bilimsel açılama nedir? & $\begin{array}{l}\text { Bilimsel yasalar ve olguların neler olduğu ve } \\
\text { bunlara nası erişilebileceği açıklamaları } \\
\text { yapılmıştır. }\end{array}$ \\
\hline Bilimsel ilerleme nasıl gerçekleşir? & $\begin{array}{l}\text { Bilim devinimsel mi yoksa birikimsel mi } \\
\text { ilerlediği }\end{array}$ \\
\hline Bilimsel gerçeklik nasıl sağlanır? & $\begin{array}{l}\text { Bilimsel gerçekliğe tümevarımla mı yoksa } \\
\text { tümden gelimle mi ulaşılır sorusunu } \\
\text { doğurmuştur. }\end{array}$ \\
\hline
\end{tabular}

$\mathrm{Bu}$ tartışmalar bilime farklı bakış açılarının gelişmesini sağlamıştır ve bilim felsefesi alanında iki temel yaklaşım söz konusudur. Bunlar pozitivist ve post-pozitivist yaklaşımlardır. 


\subsection{Bilim Felsefesinde Temel Yaklaşımlar}

Pozitivist bilim anlayışının kurucusu Comte'a göre bilimin amacı, olgular arasında var olan kesin ve sabit ilişkileri belirlemek ve doğa yasalarını bulmaktır. Bunun ancak gözlem ve deney yoluyla gerçekleşebileceği iddiasındadır. Bu yaklaşıma göre bilim insanını nesnel bilgiye götürecek en önemli ölçüt, bilim insanının sosyolojik, psikolojik ve metafizik öğelerden sıyrılabilmesidir (Tekin, 2011:8). Pozitivizm, bilginin kaynağının deney olduğunu söyler bu nedenle emprizmden destek alır. Emprizmde, bireyin gözlem ve deney yoluyla bilgiye ulaşabileceği savunulur. Pozitivizmden etkilenerek kurulan, Viyana Çevresi olarak da anılan bir grup bilim insanın Neo-pozitivizm olarak adlandırdığı yaklaşımda da deneysel yolun bilimsel yol olduğu ve bu yolla "mutlak bilgi"ye ulaşılabileceği savunulmuştur. Ancak bu çevrenin evren yaratıcısı olan Tanrı da dahil olmak üzere tüm soyut ögeleri bilim dışı olarak kabul etmesi tepkilere neden olmuştur. Mutlak bilgiye ulaşmak için izlenen yol nicel araştırmaya işaret etmektedir. Çünkü nicel araştırmalarda, araştırma sorusuna yanıt ararken sistematik ve objektif veri toplayıp bunların analiz edilmesini gerektirmektedir. Bununla birlikte nicel araştırmalarda araştırmacıdan, bilimsel araştırma sürecinin tüm basamaklarında değer yargılarını dışarıda bırakıp nesnel olması beklenir. Nicel araştırma, araştırmacı ile araştırılan konu arasındaki etkileşimin ya çok az olduğu ya da hiç olmadığı varsayımından hareket etmektedir. Araştırmacının konuya öznelliğini katmasını objektifliğin sarsılması olarak görmektedir (Koçak, 2019: 38). Pozitivizm'in, genel bakış açısı ve ona yöneltilen eleştiriler doğrultusunda sunulan alternatifler;

- Doğrulamacılığına karşı yanlışlama

- $\quad$ Emprizmine karşı akılcılık

- $\quad$ Tümevarımına karşı tümdengelim

- $\quad$ Kümülatifliğine karşı devrimsellik

- $\quad$ Bilime ilişkin ürün kabulüne karşı etkinlik kabulü

- $\quad$ Mutlak bilgiye erişmenin imkansızlığ

şeklindedir. Bu eleştiriler bir araya geldiğinde bir diğer yaklaşım olan post-pozitivist yaklaşımın temel söylemleri ortaya çıkmaktadır. Pozitivizmin savunularına karşılık getirilen eleştiriler sonucu ortaya koyulan öneriler post-pozitivizme işaret etmektedir. Bu açıdan bakıldığında pozitivizme karşı post-pozitivizm denilmesi yanlış olmayacaktır.

Newton fiziğinin çöküp yerini Einstein fiziğine bırakması, pozitivist yaklaşımın mutlak bilginin olmadığına yönelik aldığı en büyük darbedir. Frankfurt Okulu'nun, pozitivizme yönelttiği eleştiri ise araştırmacının öznel değerlerinden arınarak araştırma sürecine giremeyeceği yönünde olmuştur. Bu durumun doğa bilimleri için geçerli olabileceği ancak sosyal bilimlerde bunun sağlanmasının imkansız olduğu dile getirilmektedir. Pozitivizmin bu rasyonalite ilkesi kamusal sorunlar ve insan ilişkilerinin de bilimsel aklın gereklerine uygun olarak düzenlenmesi gerektiğini savunmaktadır (Romm, 1991: 117) ancak bunun mümkün olamayacağı yönünde eleştiriler almıştır. Pozitivizmin izlediği doğrulamacılıkta çok sayıda gözlem sonucu bir bilgiyi doğruluyorsa onun mutlak bilgi olacağ 1 iddia edilmektedir, post-pozitivizm ise iddianın doğrulanması için değil yanlış olduğu koşulların araştırılması için çaba harcanması gerektiğini savunmaktadır. Buna göre post-pozitivizmin izlediği yol, bir sorunla karşılaşılması durumda olası çözümlere ilişkin yanlışlanabilir birçok hipotez kurmak ve yanlışlananları elemektir. Süreç sonunda henüz yanlışlanmayan hipotez geçerliğini yanlışlanana kadar korur. Doğrulamacılık ilkesi ile tümevarım yolunu, yanlışlamacılık ilkesi ile de tümden gelim yolunu birlikte düşünmek gerekir. Çünkü doğrulamacılık ilkesi birçok örnekten tek bir doğru kanıya varması nedeniyle doğası gereği tümevarımı gerektirmektedir. Yanlışlamacılıkta ise, bir hipotez ya da bilgiyi doğru kabul edip bunu yanlışlayan bir örnek araması nedeniyle tümden gelimi gerektirmektedir. Son olarak pozitivizm, bilimsel araştırmanın sonucunu ön plana çıkartıp bilimi ürün olarak ele almaktayken, post-pozitivist yaklaşım ise bilimi süreç olarak değerlendirmektedir. Bunda 
pozitivist yaklaşımın tek bir yöntemi bilimsel olarak kabul etmesinin ve mutlak bilginin mümkün olduğunu savunmasının etkili olduğu ifade edilebilir. Buna karşın post-pozitivizmde, Feyerabend ve Lakatos'un tek bir bilimsel yöntem olamayacağı görüşü hakimdir (Tekin, 2011: 80). Dolayısıyla post-pozitivizm, mutlak tek bir birliğin varlığını da reddetmektedir. Elbette pozitivizmin tek doğru yöntem, tek doğru bilgi gibi tek ve mutlak tanımlamasına karşı çıkan yaklaşım yalnızca post-pozitivizm değildir. Örneğin Postmodern yaklaşım çoğulculuğu benimseyen "her şey olur" görüşüyle kendini ortaya koyan bir akımdır. "Ya öyle-ya böyle" değil, "hem öyle-hem böyle" düşüncesini benimser ve bu yönü onu çoğulcu, çok yönlü bir yaklaşım haline getirir (Erinç, 1994: 35). Buna göre Postmodern yaklaşımın da tek bir doğru, tek bir bilimsel yöntem, tek bir doğru veri toplama yolu savunularını reddettiği ifade edilebilir.

Pozitivist ve post-pozitivist yaklaşımlardan eğitim ortamları da etkilenmiştir. Eğitim bir bilim alanıdır ve her bilimin olduğu gibi eğitimin de felsefesi vardır (Murphy, Mufti ve Kassem, 2009, 32). Eğitim Felsefesi okula ve okulla ilgili tüm öğe ve süreçlere yönelik düşüncelerin ve anlamlandırma çabasıdır (Kumral, 2014: 364). Eğitim felsefesi alanında Realizm, İdealizm, İlerlemecilik ve Yeniden Kurmacılık (Kumral, 2015: 60) gibi birçok yaklaşım olmakla birlikte bilgiye, öğretmene ve öğrenciye bakış açılarına göre iki temel yaklaşımdan söz edilebilir. Bilginin mutlaklığını savunan Realist, Daimici ve Esasici akımları pozitivizt paradigma etkisinden olan eğitim felsefesi yaklaşımları, bireyin deneyimlerini ve doğruyu kendisinin bulmasının değerli olduğunu savunan Pragmatik, İlerlemeci, Yeniden Kurmacı, Varoluşçu, Hümanist akımları ise post-pozitivist paradigmanın etkisinde olan eğitim felsefesi akımları olarak sınıflandırmak mümkündür (Kumral, 2015: 60).

Mutlak bilgiyi öğrenciye aktaracak olan ise bu bilgiyi bilen kişi olan öğretmendir. $\mathrm{Bu}$ anlayışta öğretmenden en doğru bilgiye karar vermesi ve öğrencilere aktarması, öğrenciden ise bu bilgiyi olduğu gibi öğrenmesi beklenmektedir (Demirel, 2012: 72). Bu akımlar günümüzde geçerliğini korumaktadır ve geleneksel (Orstain ve Hunkins, 2018: 171) ya da klasik, pozitivist, modernist akımlar olarak adlandırılmaktadır. Pozitivist yaklaşımlarda öğretmene biçilen rol mutlak bilgiye karar verip öğrencilere aktarmasıyken, post-pozitivist yaklaşımda öğrencilerin bilgiye erişebilecekleri, kendi deneyimlerini edinecekleri ortamı sunmak ve rehberlik etmektir. Her iki yaklaşımda da öğrenme ortamının yaklaşımın biçtiği rollere göre düzenlenmesi gerektirmektedir. Bir diğer ifadeyle eğitim sürecinde kullanılan araç ve gereçler, öğretim yöntemleri ve ölçme ve değerlendirme yaklaşımları temel alınan paradigmaya göre şekillendirilmelidir. Kullanılan araç gereçlerin, öğretim yöntemlerinin bilim felsefesi ile olan ilişkisine değinilmektedir (Demirel, 2012: 72). Eğitim sürecinde kullanılan ölçme araçları ve değerlendirme yaklaşımlarının eğitim programı, öğretim yöntem ve teknikleri gibi eğitim sürecinin bir parçası olduğu düşünüldüğünde felsefi açıdan değerlendirilmesi eğitim felsefesi açısından önemlidir. Özellikle Dewey (2008: 12)'in eğitim ortamlarında mutlak bilginin olamayacağını belirtmesi üzerine bu yaklarımı benimseyen ülkeler eğitim programlarını yeniden düzenleyip, kullanılan araç-gereç ve materyalden öğretim yöntem ve tekniklerine kadar eğitim sürecinin tüm bileşenleri bu yaklaşıma uygun olacak şekilde belirlemiştir. Girdi, işlem ve çıktı olmak üzere üç basamaktan oluşan eğitimin son basamağı olan çıtı ölçme ve değerlendirmeye karşıllk gelmektedir. Bir paradigmayı temel alarak kurulan eğitim sisteminde ölçme araçlarının, madde türlerinin ve değerlendirme yaklaşımlarının da paradigmalar çerçevesinde değerlendirilmesi gerekir. Bu doğrultuda madde türlerinin bilim felsefesi ile bağı nedir ve hangi yaklaşımın etkisindedirler soruları ortaya çıkmaktadır.

\section{Test Maddelerinin Bilim Felsefesi Bağlamında İncelenmesi}

Bilim felsefesinde yer alan iki temel paradigma ışığında insan yaşamında önem taşıyan pek çok unsur tartışılmıştır. Örneğin pozitivist ve konvansiyonalist bilim anlayışları bağlamında coğrafya disiplininin konumu (Anlı, 2016: 36; Sayılan, 2017: 397) ve uluslararası ilişkiler (Güneş, 2017: 105) ele alınmıştır. Felsefe alanında Eğitim Felsefisi'nin başlı başına bir felsefe alt dalı olmasına ve eğitim süreçlerini felsefi açıdan ele almasına karşın, eğitim sürecinin en önemli parçalarından biri olan testlere yönelik bir değerlendirme yapılmamıştır. Eğitim sürecinin çıktı 
basamağı olan değerlendirme basamağı, bir ya da birkaç testin uygulanarak elde edilen puanlar doğrultusunda birey hakkında kararlar verildiği ve eğitim sisteminin diğer bileșenlerinin değerlendirildiği basamaktır. Eğitimin bir toplumun birçok yönden yapısını belirlediği düşünüldüğünde, eğitimle ilgili kararların verilmesinde dayanak olan testler de kritik bir yere sahiptir. Bu noktada, eğitimde kullanılan geleneksel ve tamamlayıcı ölçme araçlarının pozitivist ve post-pozitivist paradigmalar çerçevesinde tartışılması ve bilim felsefesi açısından madde yapılarının konumunun belirlenmesi, verilecek kararlar açısından önem taşımaktadır.

Eğitimde kullanılan geleneksel ölçme araçları, açık uçlu, çoktan seçmeli, doğru yanlış, kısa cevaplı ve eşleştirmeli madde yapılarını içermektedir. Bu madde yapılarından çoktan seçmeli madde, sorulan bir sorunun yanıtını, verilen yanıtlar arasından seçtiren maddelerdir. Çoktan seçmeli maddelerde testi alan kişiden kökte sorulan soruya yanıt verilmesi için biri doğru, diğerleri doğru olmayan öneriler yer almaktadır ve bireyin doğru olan seçeneğe yönelmesi beklenmektedir (Baykul, 2000: 107). Sorunun tek bir doğru yanıtının bulunması pozitivist paradigmanın mutlak ve tek doğru çıkışıyla paralellik göstermektedir. Bu madde türünde testi alan kişilerin çözüm yolu değil verdiği yanıt bir diğer ifadeyle ulaştıği sonuç önemlidir, sürecin değil sonucun değerlendiriliyor olması da yine pozitivist paradigma ile paraleldir. Doğru yanlış türü maddelerde de benzer durum söz konusudur. Bu madde türünde bir ifade bireye sunulur ve bu maddenin doğru ya da yanlış bir yargı ifade ettiği kararını vermesi beklenir. Buna göre sunulan ifadenin kısmen doğru olması gibi bir seçenek söz konusu olamaz ve testi alan kişi yalnızca o ifadenin doğru ya da yanlış olduğuna odaklanır. Tek bir doğru yanıtının olması ve puanlama sürecinde yalnızca sonucun değerlendirilmesi, pozitivist paradigmanın mutlak doğru kavramı ile benzerlik göstermektedir. Eşleştirmeli madde yapılarında bir grup öncül ve eşleştirilmek üzere bir başka grup ifade sunularak bireyin doğru eşleştirmeleri yapması istenir. Örneğin geometrik şekiller ve isimleri verilerek, şekil ve isim eşleşmesinin doğru olarak yapılması beklenir. Bu yönüyle bu madde yapısı da çoktan seçmeli madde yapısının bir türü olarak düşünülebilir ve aynı durumlar bu madde yapısı için de geçerlidir. Her bir ifade için tek bir doğru yanıt vardır, bireyin bunu belirtmesi beklenir. Her üç madde yapısı da bireyin başka bir doğru olamayacağı düşüncesiyle tek olan doğruyu bulmasını gerektirmektedir. Bu yönüyle her üç maddenin de pozitivist paradigma etkisinde olduğu söylenebilir.

Bir diğer madde yapısı olan açık uçlu maddede ise, çoğunlukla tek bir doğru yanıtı olmayan sorulardır bu nedenle birey kendisi açısından doğru olan bir ya da birkaç yanıtı organize ederek sunabilir. Hatta açık uçlu maddeler kimi zaman doğru olarak ifade edilebilecek yanıta sahip değillerdir ve testi alan kişinin bir durumu ya da problemi yorumlaması ve değerlendirmesi beklenir. $\mathrm{Bu}$ yönüyle bireyin duygularını, deneyimlerini, gözlemlerini, sosyal ve kültürel ögelerini verdikleri cevaba yansıtmasına imkânı tanır ve bu tam olarak pos-pozitivist paradigmanın da ön gördüğü araştırmacının sürecin dışında tutulmaması ilkesi ile örtüşmektedir. Çünkü tamamen bireysel faktörler ve kişinin görüşü etkindir yanıt verme sürecinde. Benzer şekilde sorunun tek bir doğru yanıtının olmaması, birden çok doğru yanıtının olabilmesi de postpozitivist paradigmanın pozitivist paradigmadan ayrilan temel noktalarından birine paralellik göstermektedir. Açık uçlu maddeler bireye sorunun yazılı olarak sunulduğu ve yanıtının yazılı olarak alındığı maddelerdir. Bu madde yapısının sözlü formu ise sözlü sınavlar olarak anılmaktadır. Aralarındaki fark birinde yazılı olarak sunulan sorular diğerinde sözlü olarak sunulmaktadır, bu madde yapısı da genellikle tek bir doğru yanıt içermeyen ve bireyin soruya yaklaşımda özgür olduğu madde yapıdır. Bu nedenle sözlü sınavların da pozitivist paradigma etkisinde olduğu ifade edilebilir.

Geleneksel ölçme araçlarından olan kısa cevaplı ve onun bir diğer türü olan boşluk doldurma türü maddeler, görüntü olarak açık uçlu maddeleri andırsalar da yanıtının tek bir doğru olması bakımından çoktan seçmeli maddeler gibi pozitivist yaklaşım etkisindedir. Kısa cevaplı madde yapılarının yokladığı bilişsel düzey de göz önünde bulundurulduğunda, bireyden mutlak doğru bir bilgiyi belirtmesini istemektedir. Bu bilgiyi kendi cümleleri ile ifade etmesi onun bu mutlak bilgi çerçevesinden çıkabileceği anlamına gelmemektedir. Örneğin fen ve teknoloji 
dersinde kan grupları ile ilgili, "Annesinin ve babasının kan grubu 0 olan bir çocuğun kan grubu ne olur" sorusunun yanıtı tektir ve bu tek doğru yanıtı yazması beklenir. Bu durumda doğru olan yanıtı ifade ediş şekli sonuç üzerinde etkili değildir.

Eğitimde kullanılan bir diğer ölçme aracı da performans görevleridir. Gronlund ve Linn (1995: 163), performansa dayalı durum belirlemenin hem süreç (bilgi toplama, örgütleme, analiz etme, araçları kullanma vb.) hem de ürün (yazılı rapor, deney raporu, özgün hikâye, resim veya materyal vb.) etkililiğini değerlendirme imkânı sunduğunu belirtmektedir. Performans görevleri öğrencilerin var olan yanıtlardan birini seçmek yerine ortaya özgün ürünler koyabildiği durum belirleme araçlarıdır. Performans görevleri öğrencilerin özgür düşünmelerine ve yaratıcı olmalarına olanak sağlar (Kirk ve Lund, 2002: 136). Gerçek yaşamda karşılaşılan problemleri ve çözüm yollarını dikkate alarak hazırlandığı için, birey doğru cevaba ulaşmada birden fazla yol kullanabilir ve birey yaratıcı çözümler üretebilir (Çiftçi, 2010: 940). Performansın değerlendirilmesinde sonuçtan çok sürece ağırlık verilmektedir. $\mathrm{Bu}$ durum göz önünde bulundurulduğunda, performansa dayalı durum belirlemenin de açık uçlu maddede olduğu gibi post-pozitivist paradigmanın etkisi altında olduğu ifade edilebilir.

Performansa dayalı durum belirlemede performans görevi günlük yaşamda karşılaşılan gerçek problem durumlarında öğrencilerin çözüm yolu arayışlarını ortaya koymaktadır ve bu açıdan bir bilimsel araştırma süreci izlendiği ifade edilebilir. Bu durum tam da bilim tarihinin başlangıcına karşılık gelmektedir. Mısır, Sümer ve Babiller günlük yaşantılarında karşılaştıkları sorunları çözmeye çalışırken aslında bilimin temellerini oluşturmuşlardır. Bugün kullanılan performans görevleri de bilimin çıkış noktası olan toplumun ihtiyaçlarını ve sorunları temel alarak kurgulanmaktadır. Benzer şekilde yazılı sınavların ve sözlü sınavların da günlük yaşam unsuru içermesi, bireyin bir problem durumuna ya da bir olguya karşı bakış açısı geliştirip eleştirel yaklaşması bilim tarihini metodolojisiyle örtüşmektedir. Bu madde yapılarının üçü de postpozitivist paradigma etkisindedir ancak şunu belirtmek gerekir, Feyerabend ve Lakatos'un savunduğu gibi tek bir bilimsel yöntem hâkim değildir (Tekin, 2011: 80), bu sorulara yanıt vermede kullandıkları yol bakımından özgürdür testi alanlar. Bu yönüyle de post-pozitivist paradigma etkisinde olduğu ifade edilebilir.

Özellikle performansa dayalı durum belirlemenin bireye tanıdığı özgürlük, eleştiriye açık olma bireyin gelişimini sağlamaktadır. Paul ve Elder (2001: 102) ders içeriklerinin yani kazanımlarının ancak düşünülerek edinilebileceğini, aksi halde öğrencilerin birçok bilgiyi ezberleme yoluna gideceklerini belirtmektedir. McKee (1988: 76), eleştirel düşünenin önündeki en önemli engellerden birinin öğretmenin, bireysel farklılıkları azaltmak yönünde davranması olduğunu belirtmiştir. Bu durum post-pozitivist paradigmanın savunduğu, sosyal bilimlerde ve insan ilişkilerinde bireysel faktörlerin belirleyici olacağı ilkesine de aykırıdır. Bu açıdan ele alındığında da performansa dayalı durum belirleme, bireylerin farklılıklarını kısıtlamadan yansıtmalarına hatta avantaja çevirmelerine imkân sunmaktadır.

\section{Sonuç}

$\mathrm{Bu}$ çalışmada duyuşsal ve çoğunlukla bilişsel özelliklerin ölçülmesinde kullanılan testlerde (ölçme araçlarında) yer alan madde yapılarının bilim felsefi bağlamında değerlendirilmesi amaçlanmıştır. Bu doğrultuda, pozitivist ve post pozitivist paradigmalar çerçevesinde çoktan seçmeli, doğru-yanlış, boşluk doldurma, kısa cevaplı, eşleştirmeli, açık uçlu madde yapıları ve performansa dayalı değerlendirme ile sözlü sınavlar irdelenmiştir. Sonuç olarak, çoktan seçmeli, kısa cevaplı, boşluk doldurma, eşleştirmeli ve doğru-yanlış türü maddelerin pozitivist paradigma ile uyum gösteren yapıda olduğu, sözlü sınavların, açık uçlu maddelerin ve performansa dayalı değerlendirmenin ise post pozitivist paradigmaya uygun yapıda oldukları değerlendirmesi yapılmıştır.

Çoktan seçmeli, doğru-yanlış, eşleştirmeli, kısa cevaplı ve boşluk doldurma türü maddeler bireye özgür düşünme ve yanıtlama hakkı vermemesi, soruların tek bir doğru yanıtının olması ve bu doğru yanıtlara kişisel görüşler değil, kesin ve katı bilgiler kullanılarak ulaşılabilir 
olması nedeniyle pozitivist paradigma ile örtüștüğü ifade edilebilir. Açık uçlu maddeler, sözlü sinavlar ve performansa dayalı durum belirleme ise tek bir doğru yanıt içermemesi, bireye yanıtlama sürecinde özgürlük tanıması ve dilediği yöntemi kullanma imkânı sunması bakımından post-pozitivist paradigma ile paralellik göstermektedir. Popper'ın eleştirel akılcılı̆̆ında olduğu gibi problem çözme arayışı yatmaktadır. Buna göre daima sorunlarla karşılaşı1ır ve bu sorunun çözümünde, sınama-yanılma-yanılgıyı ayıklama olarak adlandırdığ 1 bir süreci işletir. Ortaya atılan bir kuram olgusal olarak sınanır ve yanlışlanmaya çalış1ır; sonuç olumsuzsa yeni kuramlar ortaya atılır; değilse, yanlışlanmaya çalışılan kuram yanlışlanamadığı sürece korunur (Tekin, 2011: 14). Özellikle performansa dayalı durum belirlemede bireylerden beklenenin bu olduğu söylenebilir. Lacatos'un pozitivizme yönelttiği, bilimde tek bir doğrunun ya da nihai doğrunun ve yanlışın ve bilimde gerçekliği, kesin bilgiyi garanti edecek tek bir yöntem olamayacağ eleştirisi (Demir, 1992: 59), Feyerabend'in bilimsel süreçte insanın süreç dışında bırakılamayacağı ve bilimde tek bir yöntemin kabul edilemeyeceği eleştirileri de göz önünde bulundurulduğunda, sosyal bilimler alanında post-pozitivist paradigmanın hâkim olacağı şüphesizdir. Özellikle eğitim süreçleri açısından düşünüldüğünde bireye davranışlarının ve düşüncelerinin yanlış olarak değerlendirileceği algısının kazandırılmaması, onun özgür düşünmesine zemin hazırlayacaktır. Bu durum beraberinde bireyin benlik bilinci kazanmasıyla birlikte üst düzey bilişsel becerilerini geliştirme imkânı da sunacaktır. Çünkü yanlış yapmak, yanlış yanıt vermek kaygısı öğrencilerin fikirlerini ifade etmelerinin ya da doğru/mantıklı olduğunu düşündükleri fikri belirtip savunmalarının önünde büyük bir engeldir. Post-pozitivist paradigmanın 1şığında olan ölçme araçları ve değerlendirme yaklaşımları bireye bilgisini ve düşüncelerini veya bir problem durumuna yönelik çözüm önerilerini özgürce ifade edebilme ve savunabilme imkânı sunmaktadır. Post-pozitivist paradigmayı temel alan ölçme ve değerlendirme yaklaşımlarının öğretmen açısından en büyük avantajı ise öğrenciler arasındaki bireysel farklılıkları fark etmesi olacaktır. Örneğin bir sınıf öğretmeninin çevre kirliliğini konu alan problem durumunda öğrencilerinin bu soruna yönelik çözüm önerilerini incelemesi onların özgün düşünme tarzlarını ve birbirlerinden farklı yönlerini tanımasını kolaylaştıracaktır. Bir anlamda post-pozitivist paradigmayı temel alan ölçme araçları bireyin tanınmasında da katkılar sunmaktadır. Öğrencilerin ilgi alanlarına, becerilerine göre yönlendirilmesinde doğru kararlar verilmesi adına tanıma basamağı önemlidir. Benzer şekilde öğrencinin kendini tanıması, güçlü ve zayıf yönlerini fark etmesi de önemlidir. Tamamlayıcı ölçme araçlarının öz değerlendirmeyi içermesi öğrencinin kendini tanımasına katkı sağlamaktadır. Pozitivist paradigma gözlemlerin her zaman doğru olamayabileceğini, hatanın olabileceğini savunmaktadır. Öz değerlendirmede kişi hata yapabileceğini ve eksikliklerin olabileceğini fark eder. Dolayısıyla post-pozitivist paradigmaya dayalı yaklaşım ve bunun etkisinde olan ölçme ve değerlendirme yolları bireyi duygular1, ilgileri, yetenekleri ve özgür düşünme stiliyle bir bütün olarak kabul edip değerlendirmektedir.

Post-pozitivist paradigmanın araştırmacılara daha özgür bir alan tanıması ve yanlışlamacılık ilkesi gereği eleştirel bakış açısı kullanmalarını gerektirmesi nedeniyle sınıf içi değerlendirmede bu yaklaşımla paralellik gösteren performansa dayalı değerlendirme, açık uçlu madde kalıcı öğrenmeyi sağlayacağ 1 ifade edilebilir. Özellikle performansa dayalı durum belirlemenin yalnızca bir ölçme ve değerlendirme tekniği değil aynı zamanda öğrenme metodu olduğu göz önünde bulundurulduğunda, kalıcı ögrenmenin sağlanması ve bilgi ve becerilerin pekiştirilmesi noktasında başvurulabilecek yöntemdir. Çünkü bu ölçme ve değerlendirme yaklaşımları bireye özgür düşünme, düşüncesini tartışma olanağı sunmaktadır. Bu durum tam olarak eğitimde hedeflenen öğrencilere bilgiye ulaşma yollarını kazandırma amacıyla örtüşmektedir. Öğrenciler bu yöntemlerde, kendilerine verilen durumlara yönelik kendi bakış açılarını ve çözüm önerilerini geliştirip, bunları savunup tartışabilecektir. Benzer şekilde hatalı düşünebilecekleri ve bunun nasıl giderilebileceğini de araştırma imkânı olacaktır.

Eğitimin merkezinde birey olması ve bireyin hem psikolojik hem sosyal bir varlık olması göz önünde bulundurulduğunda post-pozitivist paradigmanın önerdiği gibi birden fazla teknikle birçok yönünün ölçülmesi ve değerlendirilmesi gerekir. Buna göre salt tek bir paradigmayı temel 
alan madde türlerini ve değerlendirme yaklaşımını kullanmak yerine her iki yaklaşımın sunduğu avantajlardan faydalanmak eğitimin amaçlarına ulaşmada etkili olacaktır. Günümüzde kullanılan öğretim programlarında temel alınan eğitim felsefeleri öğrenciyi merkeze alıp ona bilgiyi bulma davranışını kazandırmayı hedeflemektedir. Buna göre bireysel farklı1ıkları göz önünde bulundurarak çok yönlü düşünmeyi öğrencilere kazandırmak gerekmektedir ve tek bir doğru yolun olmadığı unutulmamalıdır.

\section{Kaynakça}

Anl1, Ö.F. (2016). The Status of Geography in The Context of Positivist and Conventionalist Understandings of Science, Journal of Thinking, 9(2): 37-59.

Arslan, A.(2007). Felsefeye Giriş, Ankara: Adres Yayınları.

Aslan, H. (2004). Bilim Felsefesinin Tarihi, Felsefe Ansiklopedisi Cilt 2, (Edt. A. Cevizci). İstanbul: Etik Yayınlar1. 423-453.

Baykul, Y. (2000). Eğitimde ve Psikolojide Ölçme: Klasik Test Teorisi ve Uygulaması, Ankara: ÖSYM Yayınları.

Çiftçi, S. (2010). İlköğretim Birinci Kademe 4 ve 5. Sinıf Öğretmenlerinin Performans Görevlerine İlişkin Görüşleri, Elementary Education Online, 9(3): 934-951.

Çilingir, L. (2016). Fen Bilimleri Öğretiminde Bilimin Doğası, (Edt. M. Demirbaş.) 2.Bask1. Ankara: Pegem Akademi. 1-21.

Demir, Ö. (1992). Bilim Felsefesi, İstanbul: Ağaç Yayınları.

Demirel Ö. (2012). Eğitimde Program Geliştirme, Ankara: Pegem.

Dewey, J. (2008). Okul ve Toplum, (Çev.: H.A. Başman), Ankara: Pegem.

Ergün, M. (t.y.). Bilim Felsefesi. http://mustafaergun.com.tr7wordpress/wpcontent/uploads/2015/11/bilimfelsefesi.pdf. (Erişim tarihi: 01.08.2018).

Erinç, S.M. (1994). Postmodernizm'in Tanımı, Konferans metni, Anadolu Üniversitesi, https://earsiv.anadolu.edu.tr/xmlui/bitstream/handle/11421/1059/103412.pdf?sequence=1\&is Allowed=y (Erişim Tarihi 08.09.2019).

Gökberk, M. (1999). Felsefe Tarihi,10. Baskı. İstanbul: Remzi Kitabevi.

Gronlund, N. E. ve Linn, R. L. (1995). Measurement and Assesment in Teaching. (7th edition), Upper Saddle River: Printice-HallInc.

Güneş, B. (2017). Uluslararası İlişkiler Disiplininde Post-pozitivist Bilim Felsefesi: Eleştirel Gerçekçilik Bağlamında Neden-Sonuç İlişkisini Yeniden Düşünmek., Türkiye'de Bilgi Üretimi ve Bilim Politikaları Sempozyumu, 15-17 Kasım, Kırşehir.

Hızır, N. (1976). Felsefe Yazıları, İstanbul: Çağdaş Yayınları.

Kirk, M. F. ve Lund, J. L. (2002). Performance Based Assessment for Middle and High School Physical Education, United States: Human Kinetics.

Kumral, O. (2014). Predicting Democratic Attitudes snd Educational Philosophies of Student Teachers, International Jurnal of Social Science \& Education, 4(2): 359-368.

Kumral, O. (2015). Öğretmen Adaylarının Eğitim Felsefeleri: Pamukkale Üniversitesi Eğitim Fakültesi Örneği, Hasan Ali Yücel Eğitim Fakültesi Dergisi, 12(2): 59-68.

Koçak, D. (2019). Eğitimde Araştırma Yöntemleri (editör: Yılmaz K ve Arık, R.S.) içinde, Bilimsel Araştırmalarda Temel Paradigmalar, 28-55. Ankara: Pegem Akademi. 
Mckee, S. J. (1988). Impediments to Implementing Critical Thinking, Social Education, 6(2): 440-446.

Murphy, L., Mufti, E., ve Kassem, D. (2009). Educational studies: An introduction, Berkshire: McGraw-Hill.

Ornstein, A. C., ve Hunkins, F. B. (2018). Curriculum. Foundations, Principles and Issues. Harlow, England : Pearson Education Limited.

Paul, R.W. ve Elder, L. (2001). Critical Thinking: Tools for Taking Charge of Your Lerning and Your Life. Upper Saddle River, Nj: Prentice Hall.

Romm, N.R.A.(1991), The Methodologies of Positivism and Marxism/A Sociological Debate, London: Macmillan.

Saraç, C. (1943). Eski Mısır'da Bilim ve Teknik, Ankara Üniversitesi Dil ve Tarih Coğrafya Fakültesi Dergisi. 1(5): 709-719.

Sayılan, H. (2017). Bilim Felsefesi Bağlamında Coğrafya Disiplini İçerisindeki Bilim Anlayışlarının Analizi, Türkiye'de Bilgi Üretimi ve Bilim Politikaları Sempozyumu, 15-17 Kasım, Kırşehir.

Tekin, Ö.F. (2011). Bilim Felsefesinde İlgi Kayması: Sonuçtan Sürece Geçiş, Yayınlanmamış Yüksek Lisans Tezi, Mersin.

Topdemir, H.G. (2002). Bilim, Bilim Tarihi ve Felsefe İlişkisi, Düşünen Siyaset, 16: 53-66.

Ural, Ş., Kaya, M., Duralı, T., Sözer, Ö., ve Erdemli, A. (1994). Felsefe Arşivi, İstanbul: Edebiyat Fakültesi Basımevi.

Yıldırım, A. ve Şimşek, H. (2006). Sosyal Bilimlerde Nitel Araştırma Yöntemleri, Ankara: Seçkin Yayınevi.

Yıldırım, C. (2000). Bilim Felsefesi, İstanbul: Remzi Kitabevi. 